\title{
The relationship between social media usage in the workplace and employee productivity in the public sector: Case study of government departments in Harare
}

\begin{tabular}{|c|c|}
\hline \multicolumn{2}{|c|}{$\begin{array}{l}\text { Authors: } \\
\text { Tawaziwa Wushe } e^{1,2} \text { (D) } \\
\text { Jacob Shenje }^{3} \text { (D) }\end{array}$} \\
\hline \multicolumn{2}{|c|}{$\begin{array}{l}\text { Affiliations: } \\
{ }^{1} \text { College of Economic and } \\
\text { Management Sciences, } \\
\text { University of South Africa, } \\
\text { Pretoria, South Africa }\end{array}$} \\
\hline \multicolumn{2}{|c|}{$\begin{array}{l}{ }^{2} \text { Country Cool Air } \\
\text { Conditioning Pvt Ltd, Harare, } \\
\text { Zimbabwe }\end{array}$} \\
\hline \multicolumn{2}{|c|}{$\begin{array}{l}{ }^{3} \text { Decision Point Consultants } \\
\text { Pvt Ltd, Harare, Zimbabwe }\end{array}$} \\
\hline \multicolumn{2}{|c|}{$\begin{array}{l}\text { Corresponding author: } \\
\text { Tawaziwa Wushe, } \\
\text { tawaziwa@countrycool.co.zw }\end{array}$} \\
\hline \multicolumn{2}{|c|}{$\begin{array}{l}\text { Received: } 16 \text { Aug. } 2018 \\
\text { Accepted: } 18 \text { Apr. } 2019 \\
\text { Published: } 05 \text { Nov. } 2019\end{array}$} \\
\hline \multicolumn{2}{|c|}{$\begin{array}{l}\text { How to cite this article: } \\
\text { Wushe, T., \& Shenje, J. (2019). } \\
\text { The relationship between } \\
\text { social media usage in the } \\
\text { workplace and employee } \\
\text { productivity in the public } \\
\text { sector: Case study of } \\
\text { government departments } \\
\text { in Harare. SA Journal } \\
\text { of Human Resource } \\
\text { Management/SA Tydskrif vir } \\
\text { Menslikehulpbronbestuur, } \\
\text { 17(0), a1116. https://doi.org/ } \\
\text { 10.4102/sajhrm.v17i0.1116 }\end{array}$} \\
\hline \multicolumn{2}{|c|}{$\begin{array}{l}\text { Copyright: } \\
\text { (C) 2019. The Authors } \\
\text { Licensee: AOSIS. This } \\
\text { is licensed under the } \\
\text { Creative Commons } \\
\text { Attribution License. }\end{array}$} \\
\hline \multicolumn{2}{|l|}{ Read online: } \\
\hline 口rits & $\begin{array}{l}\text { Scan this QR } \\
\text { code with your } \\
\text { smart phone or } \\
\text { mobile device } \\
\text { to read online. }\end{array}$ \\
\hline
\end{tabular}

Orientation: The advent of social media has taken new dimensions becoming one of the most significant methods of how people communicate all over the world. In particular, the usage of social media and networking sites is a phenomenon that has brought great negative and positive impact to organisations and employees nowadays.

Research purpose: The primary aim of the study sought to determine the relationship between social media usage in the workplace and employee productivity in the public sector with particular reference to government departments in Harare.

Motivation for the study: There have been rising concerns about the use of social media sites in the workplace because of loss of labour productivity through time wasted at work.

Research approach/design and method: The study adopted a positivist research approach because it had ontological assumptions of representationalism and objectivism. Because of the nature of the research objectives, a descriptive research design was found to be necessary. A sample size of 278 management and employees from five selected government departments was targeted. Structured questionnaires were used for the collection of relevant primary data.

Main findings: The study revealed that social media usage in the workplace resulted in significant drop in employees' productivity because of time spent online keeping in touch with friends, sharing pictures and communicating with colleagues.

Practical/managerial implications: As social media cannot be completely eradicated during working hours, the human resources departments need to monitor deadlines and job deliverables with the need to ensure that jobs are performed efficiently.

Contribution/value-add: The study sought to fill the existing research gaps with regard to the use of social media at workplace and employee productivity.

Keywords: networking sites; performance; productivity; public sector; social media.

\section{Introduction}

\section{Orientation}

The advent of social media as a technological innovation has taken new dimensions by becoming one of the most significant ways of how people communicate globally (Awolusi, 2012; Bolton, Kabadayi, Gruber, Loureiro, \& Solnet, 2013; Von, 2015). In particular, the usage of social media and networking sites such as WhatsApp, Facebook, Skype, Twitter, You Tube, Instagram and LinkedIn has become a phenomenon that has brought both negative and positive impact to various organisations and employees nowadays. According to Sultana, Abdullah and Tabassum (2013) and Tilahun (2016), more and more people have been using social networking sites to connect with colleagues, friends, family as well as making collaborations. The social media has indeed gained entry and popularity into the workplace where it has not only affected employee skills, abilities, knowledge, qualification and motivation levels but also productivity and job performance (Munene, 2016; Tilahun, 2016). Thus, the ubiquity of these social media platforms in the workplace can no longer be ignored anymore because of their effect on employee productivity and performance. Wasting time through social media activities is a huge hidden cost to any organisation. As noted by Aguenza, Al-Kassem and Mat Som (2012), social media has become a time waster with more than $65 \%$ of employees globally visiting the sites at least once a day. 
In Zimbabwe, there have been rising concerns about the use of social media sites in the workplace because of loss of labour productivity. Indeed, there had been growing worry among government departments that employees had been wasting much time on these social media sites during working hours resulting in reduced productivity. For instance, it has been noted that, on average, employees spend at least 2 hours per day on Facebook, WhatsApp, Skype and/or Twitter in the workplace (Mhiripiri \& Mutsvairo, 2013). In the face of slow and inefficient service delivery, government departments in Harare had not thought of deeply looking into what had been eating up employee work hours without commensurate results. In some instances, staffs had been with their computer systems or mobile phones blogging or tweeting for their personal motives and gains during working hours (Munene, 2016; Shava, Chinyamurindi, \& Somdyala, 2016). It also seems that government employees had been spending their time on social media networks to non-work-related activities such as creating personal relations, listening music and watching videos. When employees spend many hours on social media, performance in government departments is bound to be affected. One of the challenges facing government departments in Harare has been to enhance productivity of the workforce to improve service delivery and avoid of scarce resources wastage. Thus, the introduction of Internet and smartphones has caused and raised issues of the relationship between social media usage and employee productivity in the workplace because of the time being spent on non-work-related activities. Indeed, the introduction of smartphones has compounded the challenge in question and subsequently has become a distraction at work as employees can easily connect to social media sites.

There had been considerable conflicting arguments among scholars on the impact of social media usage in the workplace on employee productivity. For instance, Aknin, Elizabeth, Ashley, Adam and Michael (2013) and Richards (2012) argue that employees who use social media sites in the workplace are $15 \%$ more productive than those who do not. Alternatively, other scholars believe that social media use in the workplace has resulted in sharper employees' lack of concentration and reduced work productivity. For instance, studies by Razmerita, Philips-Wren and Jain (2015) noted that the use of Facebook at work results in a $1.5 \%$ decrease in productivity. Therefore, the study sought to fill the existing research gap and resolve this debate by attempting to fulfil the following research objectives:

- Determine the relationship between time spent on Facebook and employee productivity.

- Determine the relationship between time spent on WhatsApp and employee productivity.

- Establish the association between time spent on Twitter and employee productivity.

- Establish the association between time spent on Skype and employee productivity.

- Determine the relationship between time spent on LinkedIn and employee productivity.
In line with the above research objectives, the following research hypotheses were tested at $5 \%$ level of significance:

H1: Time spent on Facebook has a negative relationship with employee productivity.

H2: Time spent on WhatsApp has a negative relationship with employee productivity.

H3: Time spent on Twitter has a negative relationship with employee productivity.

H4: Time spent on Skype positively has a negative relationship with employee productivity.

H5: Time spent on LinkedIn has a negative relationship with employee productivity.

\section{Literature review}

\section{Concept of social media and online social networking}

Social media can be described as an online service or platform that focuses on facilitating building of social networks or social relations among people who share the same or similar interests, activities, backgrounds or real-life connections (Bolton et al., 2013). These online platforms allow individuals to have public or semi-public profile within a bounded system, view and traverse various lists of connections made by others within the system. Examples of online social networking and social media sites include Twitter, LinkedIn, Facebook, Skype, Sphere, Amazon, YouTube, Nexopia, 2go, Ebay, Bebo, Badoo, Hi5 and so on (Holtzblatt, Drury, Weiss, Damianos, \& Cuomo, 2013; Twenge, 2010). These social media sites have general basic features like user names with personal passwords and biographical profiles of users.

There has been growth in popularity of social media sites in both developing and developed countries and its advancement has promptly changed how organisations work and communicate. According to Munar, Gyimóthy and Cai (2013), private and public organisations have now been forced to work with social media because of its effectiveness as a two-way communication and effective collaboration. Despite scepticism on its value because of data leakage from staff gossiping freely in an open environment and phishing scams, there has been recognition by many organisations that social media and networking sites in the workplace result in improved employee productivity (Cai, Huang, \& Liu, 2018; Harandi \& Abdolvand, 2018). The biggest concern of social media usage in the workplace has been the reduction on employee productivity from time wastage.

\section{Theoretical model: Distraction-conflict theory}

Sanders, Baron and Moore (1978) explored the distractionconflict theory in explaining how particular distraction can affect the performance of an individual on a given task. These distractions can be behavioural or psychological or social or non-social and are often triggered by competing activities or environmental stimuli (Mushwana \& Bezuidenhout, 2014). According to the theory, distractions and interruptions consume employees' time that could be spent on critical tasks. As such, individuals are subject to distractions caused 
by secondary tasks that disrupt their ability in the workplace (Awolusi, 2012).

The theory also states that distractions constitute any stimuli irrelevant to the task at hand which can produce attentional conflict between the primary task and the distractor (Speier, Valacichm, \& Vessey, 1999), for instance, when Facebook distracts an employee, he or she may forget the information needed to process primary tasks and cues may be lost (Ribière, Haddad, \& Philippe Vande, 2010). This cognitive difficulty is usually associated with time lags in regaining the mental state held before the distraction. As a result, actual productive time would be lost because of distraction (Patel \& Jasani, 2010). Using distraction-conflict theory, the study argues that checking a social media platform such as Facebook, Twitter, Skype or YouTube during working hours could result in employees processing multiple inputs (Can \& Kaya, 2016; Young, 2017). The theory provides insight into evaluating social media as an instrument that distracts employees from their primary tasks. When employees are exposed to interruption or distractions, these may affect mental attention and impair task processing.

\section{Relationship between social media usage and employee productivity}

Various studies have attempted to determine the relationship between social media usage in the workplace and employee productivity. Social media has been credited for helping employees to become more productive and allow them to stay current with market trends as well as other issues important to consumers. As postulated by Salanova, Llorens and Ventura (2014), the use of social media sites may actually increase employee productivity as they become connected to other skilled people through social media sites as well as improved communication channels and sharing of skills. In addition, using analytical tools, companies have been able to transform social networking sites like Facebook or Twitter into mines of market research information where businesses recognise trends as information about how customers interact with their employees (Wilson, 2009). Duff, Brittany and Sela (2015) also noted that social media platforms such as Facebook, Twitter and Skype can allow employees to instantly see creative work of their colleagues and can help users to brainstorm new ideas. Furthermore, Wang, Yang and Chen (2016) expound that the usage of Facebook has been credited with helping employees to be $9 \%$ more productive in the workplace. In the same vein, Tarafdar, Pullins and Ragu-Nathan (2015) established that the intensity of Facebook use by employees in an organisation was related to life satisfaction and social trust. Maier, Laumer, Weinert and Weitzel (2015) also opine that Facebook usage by employees can be the strength for organisations when used to expand networks and increase access.

Companies such as IBM have used social networking sites to enhance innovative behaviour by establishing its own internal social network called Beehive, which allows activities such as photo-sharing and discussion groups among employees (Aguenza et al., 2012; Maier et al., 2015). In fact,
Abdulahi, Samadi and Gharleghi (2014) argue that social networking sites, such as Facebook, Twitter, Skype and LinkedIn, encourage sociability and this is essential for growth and satisfaction in the workplace. A survey on 1731 participants recruited from Mechanical Turk concluded that there were positive associations between the distraction felt from social media such as Facebook as well as YouTube and employee productivity (Hysa, Mularczyk, \& Zdonek, 2015).

However, there are other academics and practitioners who argue that social media usage in the workplace has a negative relationship with employee productivity. For instance, Hysa et al. (2015) argue that the average Internet user can spend, on average, 2 hours a day and $6 \mathrm{~h}$ per month on Facebook in the workplace. A study in the United Kingdom indicated that social media use in the workplace has been responsible for as much as $£ 132$ million per day of lost productivity and 233 million hours lost every month (Gravili, 2010; Jarrahi \& Sawyer, 2012). The productivity loss and time wasted in the workplace happen because some of these social media sites are addictive. Organisations are also worried that social networking sites such as Facebook and Twitter are used by hackers to distribute malware using trusted accounts. Consequently, this breaches a company's security if employees click on malicious site links (Cao, Vogel, Guo, Liu, \& Gu, 2012).

The other challenge for organisations on social media usage in the workplace has been the difficulty of distinguishing whether the employees post personal views or views of the company they work for. Another negative consequence of using social networking sites in the workplace is the consumption of extra bandwidth that would end up affecting the efficiency of core business tasks. According to Shami, Nichols and Chen (2014), social networking sites, such as YouTube, are high-bandwidth sites that consume between $75 \%$ and $90 \%$ of bandwidth within most organisations. For instance, the use of Facebook at work results in a 3.5\% decrease in productivity. The wasted productivity would add up to money lost through wages and decreased efficiency. In a sample of over a thousand business professionals, employees admitted to routinely checking their Facebook, LinkedIn and Twitter 'inboxes' throughout the workday (Munar et al., 2013). Such routine checking of social media sites at work has been found to have negative effects.

Another survey study of more than 168000 in France by Ribière et al. (2010) found that $48 \%$ of employers believe that the use of social media in the workplace had a negative impact on employee productivity. Flynn (2011) and Kane (2017) also concluded that social networking platforms negatively affect employee's performance by decreasing their abilities and close association with organisation. From the preceding literature discussion, it can be argued that the relationship between social media usage in the workplace and employee productivity offers inconsistent and inconclusive findings. Some of the studies reviewed argued that there is a positive relationship between social 


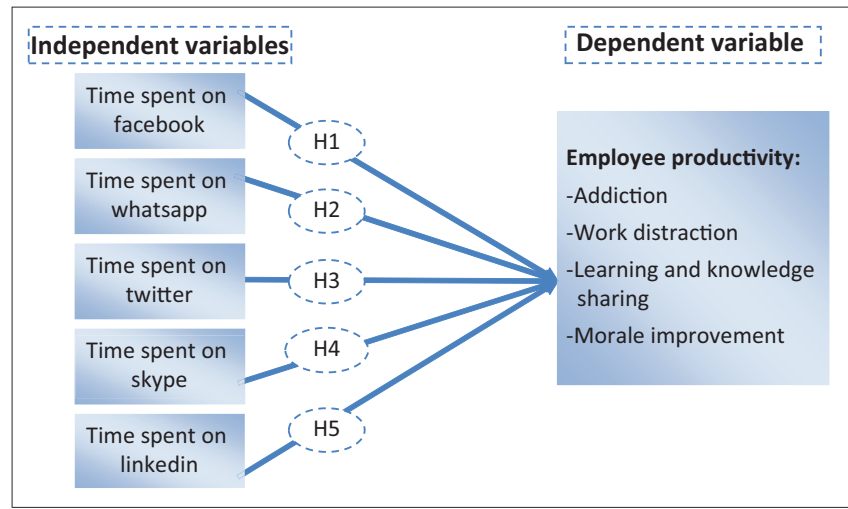

$\mathrm{H}$, hypothesis.

FIGURE 1: Conceptual model.

media usage in the workplace and employee productivity, whilst other studies established negative correlation. Thus, the study will seek to provide a conclusive answer on the effect of social media usage in the workplace on employee productivity.

\section{Conceptual model}

Based on the literature that has been reviewed, a conceptual model has been proposed that consists of the identified social media platforms discussed and employee productivity. These platforms include Facebook, WhatsApp, Twitter, Skype and LinkedIn. These social media platforms that widely appear in the literature are embedded within social media usage in the workplace and have been relatively essential in determining employee productivity. These social media platforms in this study are measured as multidimensional constructs whereby social media usage is the proxy for employee productivity. The diagram in Figure 1 illustrates the relationship between independent variables (social media applications) and the dependent variable (employee productivity).

\section{Methodology \\ Research design}

The study adopted a descriptive research design because it helped the researchers to generalise and apply the findings beyond the situation in which the study was originally conducted. In addition, the use of descriptive research design assisted the researchers in generating testable hypotheses through deductivism. In line with suggestions by Bryman and Bell (2015), the use of descriptive research design helped the researchers in expanding more output for the study as it sought to determine how the use of social media in the workplace would cause changes in employee productivity. As such, the object of the study was to investigate the relationship between time spent on various media platforms as the independent variables and employee productivity as the dependent variable. More so, the use of descriptive research design also helped the researchers in minimising biases and any values that could contaminate the research process. As such, descriptive research design provided a self-corrective tool that checked credibility of primary data credibility and reduced the distortion because of researchers' subjectivity.
In addition, a descriptive research design would be able to detect the fine differences between respondents selected from various government departments. Therefore, this would allow the researchers the opportunity to categorise social media usage at workplace using demographic variables. Above all, the use of a descriptive research design would explicate the study problem by collecting numerical data and analyse using statistical tools (Hair, 2015). As such, the use of a descriptive research design allowed the researchers to use consistent measurements that would stand the test of time and is free from biasness.

\section{Population and sample size}

The population of the study was broadly defined as employees and management derived from selected government departments in Harare. The study population was estimated at 1000 employees and management from five selected government departments in Harare. Thus, the choice of the population was driven by the need to extract informed and relevant information pertaining to the relationship between social media usage in the workplace and employee productivity in the public sector. From the study population of 1000 employees and management, it was critical to select a sample size that was representative of the whole target population. For the purposes of this study, the sample size was calculated using the following formula by Wiid and Diggines (2011):

$$
\mathrm{n}=\mathrm{N} / 1+\mathrm{N}\left(\mathrm{e}^{2}\right)
$$

where

$\mathrm{n}=$ expected sample size

$\mathrm{N}=$ the population

$\mathrm{e}=0.05$, the level of precision.

From the above statistical formula, the sample size for the study at $5 \%$ level of significance was $n=1000 / 1+10000$ $(0.052)=278$ respondents

\section{Sampling techniques}

After ascertaining the sample size, the researchers sought to pick the participants using the appropriate sampling techniques. Accordingly, the study sample was divided into homogeneous groups that included five selected government departments in Harare. The allocation of each stratum was performed using proportional sampling and this was calculated using the following formula:

$$
n i=n * N i / N
$$

[Eqn 2]

where

$\mathrm{ni}=$ number of members in the sample from strata $i$ for $i=1$, $2 \ldots . .5$

$N i=$ number of members in the population from strata $i$ for $i=1,2, \ldots \ldots .5$

$N=$ number of members in the entire population $n=$ sample size.

Table 1 shows the proportional sampling derived from the selected government departments. 
TABLE 1: Proportional sampling

\begin{tabular}{lc}
\hline Sample & $\begin{array}{c}\text { Stratified sampling } \\
\text { (ni = n*ni/n) }\end{array}$ \\
\hline Government department A & 56 \\
Government department B & 54 \\
Government department C & 56 \\
Government department D & 60 \\
Government department E & 52 \\
\hline Total & $\mathbf{2 7 8}$ \\
\hline
\end{tabular}

Within the identified strata, simple random sampling technique was utilised. As the expectation of the study was to generalise the collected data to government departments in Harare, simple random sampling was appropriate. The advantage of simple random sampling was that it permitted the estimation of the sampling error which could be minimised and calculated (Zikmund, Babin, Carr, \& Griffin, 2013).

\section{Research instrument}

Structured questionnaires were used for the collection of relevant primary data from employees and management. The use of the structured questionnaires helped in capturing the attitudinal data of respondents. Furthermore, survey questionnaires were simple to administer and helped in maintaining objectivity of the study whilst ensuring that the answers directly addressed issues at stake (Easterby-Smith, Thorpe, \& Jackson, 2012). Moreover, the questionnaires enabled the busy employees and management to complete them at their own convenience thereby ensuring a higher response rate for the study.

Structured questions used to measure the effect of social media usage at workplace on employee productivity were adapted from Aguenza et al. (2012), Naheed (2014) and Tilahun and Yeshambel (2016). A five-point Likert scale was used to measure the relationship between social media variables and employee productivity. The Likert scale gave the respondents the opportunity to indicate the degree of agreement or disagreement to a series of provided statements. The five-point Likert scale gives the respondents more options to choose with point 1 indicating strong disagreement, 2 indicating disagreement, 3 showing neither agreement nor disagreement, 4 indicating agreement and 5 indicating strong agreement (Malhotra, 2010; Scandura \& Williams, 2013). The benefit of the Likert scale type questions was that it made the questionnaire easy to construct and was relatively easy for respondents to understand how to use the scale.

\section{Research procedure and ethical considerations}

The questionnaires were administered through the use of drop and pick method. This involved leaving the questionnaires with the respondents and then picking them at a later date when completed. The main advantage of the drop and pick method was that it resulted in significantly higher response rates (Hair, Black, Babin, \& Anderson, 2010). The drop and pick method gave respondents enough time to answer the questionnaire because the researchers would come later to pick them. Furtherance, the pick and drop method allowed the researchers to collect data from a large representative sample at relatively low cost per datum. To enable the participants to fully understand the context of the survey, an introductory brief was attached to the first page of the questionnaire. The cover letter stated that participation was completely voluntary, with assurance of strict confidentiality. During the dropping of the questionnaires, the researchers established rapport with the respondents to encourage them to respond to the data collection instruments accurately. The distribution of questionnaires began from 23 June 2018 to 23 July 2018.

\section{Data analysis}

The collected data were collated, coded and entered Statistical Package for Social Sciences (SPSS) version 25. The statistical programme was used to analyse the demographic characteristic of the respondents and to obtain the result by frequencies and percentage. As the study was quantitative in nature, the findings were presented in simple descriptive statistics involving some tables and bar charts. Pearson correlation techniques measured the relationship between the variables of social media and employee productivity. Regression analysis was also employed for drawing results.

\section{Ethical considerations}

The ethical considerations conserved in the study included anonymity of respondents, confidentiality of primary data as well as seeking permission to conduct research from relevant authorities such as management of the respective authorities.

The researchers had ethical obligations to respect the rights, needs, values and desires of the respondents. Accordingly, primary data collected from the respondents were treated with utmost confidentiality without any disclosure of their personal identity. The researcher promised confidentiality and did not ask for the names of the respondents. In line with recommendations by Sekaran and Bougie (2013), all the study respondents were assured that the primary data obtained from the study would be kept confidential, and hence, they could feel confident to express their opinion without fear and concern. The researchers also ensured that anonymity of the participants was maintained through the removal of any identifying characteristics before the dissemination of information. It was also assured that all collected data would be analysed and reported only in aggregate form. The questionnaire data were kept confidentially and respondents were assured of their right to withdraw at any time. The names of the respondents were not recorded and so all the data were rendered anonymous.

\section{Results}

From a total of 278 randomly distributed questionnaires to the five selected government departments in the central business district of Harare, the study managed to realise 
210 questionnaires. This represented a response rate of $75.5 \%$ and was high enough to make reliable analysis and conclusions in relation to the effect of social media usage at workplace on employee productivity in the public sector. The response rate agrees with suggestions by Mugenda and Mugenda (2012) who argue that a response rate above $60 \%$ is adequate enough to make meaningful primary data analysis.

A reliability test was performed on the study's constructs (Facebook, WhatsApp, Twitter, Skype and LinkedIn) using the Cronbach's alpha test. According to Salkind (2012), Cronbach alpha measures whether the collected data will be good enough to be endured even more using advanced statistical procedures. Babbie and Mouton (2012) suggest that Cronbach alpha values should be at least 0.7 to be acceptable. Table 2 shows the Cronbach's alpha values.

From Table 2, it can be seen that the Cronbach alpha's values for the study variables such as Facebook (0.8), WhatsApp (0.82), Twitter (0.79), Skype (0.75), LinkedIn (0.86) and employee productivity (0.81) were more than acceptable. Thus, items in the study satisfactorily measured variables for the study.

The researchers sought to determine the biographic data of the sample used for collecting primary data. In particular, background information relating to age, gender, monthly income, marital status and educational qualifications were analysed. All these are shown in Table 3.

From Table 3, majority of the respondents were men (54\%) and the average age category for the respondents was 31-40 years (43\%). This is an economically active and young group consisting of mainly millennials and Generation K.

TABLE 2: Reliability test.

\begin{tabular}{lcc}
\hline Variable & Number of items & Cronbach's alpha \\
\hline Facebook & 7 & 0.80 \\
Whatsapp & 7 & 0.82 \\
Twitter & 7 & 0.79 \\
Skype & 7 & 0.75 \\
Linkedln & 7 & 0.86 \\
Employee productivity & 7 & 0.81 \\
\hline
\end{tabular}

TABLE 3: Demographic characteristics of the respondents.

\begin{tabular}{llc}
\hline Demographic variable & Category & Valid per cent \\
\hline Age of respondents & Below 20 years & 12 \\
& 20 years to 30 years & 24 \\
& 31 years to 40 years & 39 \\
& 41 years to 50 years & 17 \\
& Above 50 years & 8 \\
Gender of respondents & Males & 54 \\
Level of education & Females & 46 \\
& Diploma & 23 \\
& Undergraduate degree & 56 \\
& Master's degree & 21 \\
Working experience & Doctorate degree & - \\
& 1 year to 5 years & 20 \\
& 6 years to 10 years & 40 \\
& 11 years to 15 years & 31 \\
& Above 15 years & 9 \\
\hline
\end{tabular}

More, so these are also frequent users of social media in both public and private organisations (Razmerita et al., 2015). In addition, majority of the respondents (85\%) had been with their respective government department for a period of at least 6 years. In terms of educational qualifications, most of the respondents $(77 \%)$ had at least a university degree. As such, the respondents were educated enough to understand issues pertaining to the effect of social media usage at workplace on employee productivity in the public sector. This provided credibility that the findings from the survey were collected from respondents who understood and could interpret the questionnaire on their own.

Pearson correlation analysis was used to determine the level of relationship between the study's independent variables of social media applications (WhatsApp, Facebook, Skype, LinkedIn and Twitter) and dependent variable of employee productivity. As these variables were largely continuous, Pearson correlation was believed to be the most appropriate analysing technique in describing the direction and strength of the linear relationship (Shami et al., 2014). This was also in line with Creswell (2013) who argued that Pearson correlation matrix can be used to measure relationships between independent and dependent variables in a study. Table 4 shows the relationship among independent variables of social media use and the dependent variable of employee productivity.

Based on the correlation matrix shown in Table 4, Facebook has a negative and significant correlation with employee productivity $(r=-0.317, p<0.05)$ at 0.05 level of significance. This invariably implies that any increase in the use of Facebook by government employees during working hours will result in simultaneous decrease productivity in terms of work distraction, learning and knowledge sharing and morale improvement. Thus, the hypothesis that time spent on Facebook has a negative relationship with employee productivity is accepted based on the sampled data.

The Pearson correlation also showed that time spent on WhatsApp has a negative and significant relationship with employee productivity $(r=-0.225, p<0.05)$. These findings imply if the government employees increase use of Whats App during working hours, this will ultimately result in decreased employee productivity. Thus, we accept the hypothesis that time spent on WhatsApp has a negative relationship

TABLE 4: Correlation analysis.

\begin{tabular}{lcccccc}
\hline Variable & $\mathbf{1}$ & $\mathbf{2}$ & $\mathbf{3}$ & $\mathbf{4}$ & $\mathbf{5}$ & $\mathbf{6}$ \\
\hline Facebook & 1.000 & - & - & - & - & - \\
WhatsApp & $-0.296 *$ & 1.000 & - & - & - & - \\
Twitter & $-0.114 *$ & $-0.096^{*}$ & 1.000 & - & - & - \\
Skype & $-0.293^{*}$ & $-0.322 *$ & $-0.279 * *$ & 1.000 & - & - \\
Linkedln & $-0.181 * *$ & $-0.397 * *$ & $-0.417 * *$ & - & 1.000 & - \\
Productivity & $-0.317 *$ & $-0.225 *$ & $-0.273 *$ & $-0.408 *$ & $0.502 *$ & 1.000 \\
\hline
\end{tabular}


with employee productivity based on the sampled data. In addition, the study revealed that time spent on Twitter at work showed a negative and significant correlation with employee productivity $(r=-0.273, p<0.05)$. The result invariably implies that any increase in time spent on Twitter by employees during working hours would result in negative productivity. Thus, we accept the hypothesis that time spent on Twitter negatively affects productivity of employees at workplace on the basis of the sample data.

The study also revealed a negative and significant negative relationship between time spent on Skype during working hours and employee productivity $(r=-0.408, p<0.05)$. Thus, the result implies that using Skype during working hours will negatively affect employee productivity in the government departments. As such, we accept the hypothesis that time spent on Skype positively has a negative relationship with employee productivity on the basis of the sampled data. Furthermore, the survey findings disclosed a positive and significant relationship between LinkedIn and employee productivity $(r=0.502, p<0.05)$. This implies that use of LinkedIn at work positively influences employee productivity in the government departments. Thus, we reject the hypothesis that time spent on LinkedIn has a negative relationship with employee productivity on the basis of sampled data.

Regression analysis was used to identify the predictors of employee productivity as conceptualised in the research model. As such, regression analysis sought to identify how much each independent variable affected on the dependent variable. The findings are shown in Table 5.

From the above findings, the regression coefficient of all types of social media (WhatsApp, Facebook, Skype, LinkedIn and Twitter) was estimated at $r=0.452$. The adjusted $R^{2}$ coefficient of determination which shows the variation between in the dependent variable because of changes in the independent variable was $R^{2}=0.280$. This shows that about $28 \%$ of employee productivity in the government departments can be explained by the five types of social media such as WhatsApp, Facebook, Skype, LinkedIn and Twitter. This shows that the whole model was significant. In other words, this means that there is an overall effect for social media use at workplace on employee productivity.

One-way analysis of variance (ANOVA) was used to analyse the significance of the various models in the study. The findings are shown in Table 6.

Table 6 shows that the model is statistically significant (sig. $=0.000)$, in which the $F$-value is equal to 15.852 . The

TABLE 5: Regression analysis - model summary.

\begin{tabular}{lcccc}
\hline Model & $\boldsymbol{R}$ & $\boldsymbol{R}$ square & Adjusted $\boldsymbol{R}$ square & Std. error of the estimate \\
\hline 1 & $0.452 \dagger$ & 0.325 & 0.280 & 0.42784 \\
\hline
\end{tabular}

Std. standard.

$\dagger$, Predictors: (Constant), WhatsApp, Facebook, Skype, LinkedIn, Twitter. model shows that the significance level is less than 0.05 , a sign of approval that there exists a relationship between employee productivity and independent variables of the study. A regression model was also used to allow a simultaneous analysis of the impact of the five variables. The results from the findings are shown in Table 7.

From the findings, it was established that the study showed a statistical significant relationship with $p<0.05$. Moreover, the findings revealed that a unit increase in Facebook usage at workplace would result in employee productivity declining by a factor of $0.477(47.7 \%)$. In addition, a unit increase in WhatsApp usage at workplace would lead to a decrease in employee productivity by factor of $0.416(41.6 \%)$ and a unit increase in Skype usage at workplace would result in declining employee productivity by a factor of $0.086(8.6 \%)$. The study also revealed that a unit increase in Twitter would lead to decrease in employee productivity by a factor of 0.038 (3.8\%). However, it was revealed that a unit increase in LinkedIn usage at workplace would lead to an increase in employee productivity by factor of $0.216(21.6 \%)$. From the findings, Facebook $(p=0.000)$, WhatsApp $(p=0.004)$, Skype $(p=0.000)$, Twitter ( $p=0.001)$ and LinkedIn $(p=0.005)$ were all significant in predicting employee productivity in government departments because the $p$ values were less than 0.05 . Thus, the findings vividly show the magnitude of the correlation between social media usage at workplace and employee productivity in the public sector.

\section{Discussion}

The correlation results showed that time spent on social media applications such as WhatsApp, Twitter, Skype and Facebook had a negative relationship with employee productivity. The findings suggested that employees may be spending most their time on these social media platforms engaging in non-work-related activities. The regression model showed that the model was significant and that

TABLE 6: Analysis of variance analysis (one-way analysis of variance). $\dagger$

\begin{tabular}{lccccc}
\hline Model $\mathbf{1}$ & Sum of squares & df & Mean square & $\boldsymbol{F}$ & Sig. \\
\hline Regression & 14.509 & 5 & 2.902 & 18.422 & $0.000 \%$ \\
Residual & 5.491 & 30 & 0.183 & - & - \\
\hline Total & $\mathbf{2 0 . 0 0 0}$ & $\mathbf{3 5}$ & - & - & - \\
\hline
\end{tabular}

Sig., significance; $d f$, degree of freedom.

$\dagger$, Dependent variable: Employee productivity.

$\ddagger$ Predictors: (Constant), WhatsApp, Facebook, Skype, LinkedIn, Twitter

TABLE 7: Regression model results - coefficients. $\dagger$

\begin{tabular}{|c|c|c|c|c|c|}
\hline \multirow[t]{2}{*}{ Model 1} & \multicolumn{2}{|c|}{$\begin{array}{l}\text { Unstandardised } \\
\text { coefficients }\end{array}$} & \multirow{2}{*}{$\begin{array}{c}\begin{array}{c}\text { Standardised } \\
\text { coefficients }\end{array} \\
\text { Beta }\end{array}$} & \multirow[t]{2}{*}{$t$} & \multirow[t]{2}{*}{ Sig. } \\
\hline & $\boldsymbol{B}$ & Std. error & & & \\
\hline (Constant) & 6.114 & 0.838 & - & 7.292 & 0.000 \\
\hline Facebook & -0.477 & 0.121 & -1.018 & -7.251 & 0.000 \\
\hline WhatsApp & -0.416 & 0.225 & -0.395 & -1.851 & 0.004 \\
\hline Skype & -0.086 & 0.186 & -0.057 & -2.460 & 0.000 \\
\hline Twitter & -0.038 & 0.132 & 0.060 & -1.285 & 0.001 \\
\hline LinkedIn & 0.216 & 0.098 & 0.301 & 2.204 & 0.005 \\
\hline
\end{tabular}

Std., standard; Sig. significance.

$\dagger$, Dependent Variable: Employee productivity. 
about $28 \%$ of employee productivity in the government departments could be explained by the five types of social media such as WhatsApp, Facebook, Skype, LinkedIn and Twitter. Furthermore, the ANOVA analysis showed that the model was statistically significant $($ sig. $=0.000)$, a sign of approval that there existed a relationship between employee productivity and independent variables of the study. More interesting, the findings revealed that a unit increase in usage of WhatsApp, Twitter, Skype and Facebook during working hours would result in employee productivity declining. These social media platforms have been widely linked with making individuals more self-centred and decrease in a person's attention span in the workplace (Cai et al., 2018; Harandi \& Abdolvand, 2018). In relation to the findings, De Wet, Koekemoer and Nel (2016) argued that using social media sites during working hours may actually decrease employee productivity. The findings also agree with a study in the United Kingdom by Jarrahi and Sawyer (2012) which indicated that social media use in the workplace had been responsible for as much as $£ 132$ million per day of lost productivity and 233 million hours lost every month. From the findings, Facebook $(p=0.000)$, WhatsApp $(p=0.004)$, Skype $(p=0.000)$, Twitter $(p=0.001)$ and LinkedIn $(p=0.005)$ were all significant in predicting employee productivity in government departments because the $p$ values were less than 0.05 . Thus, the findings vividly showed the magnitude of the correlation between social media usage at workplace and employee productivity in the public sector and was able to test all the research hypotheses.

The correlation results also revealed that time spent on LinkedIn had a positive relationship with employee productivity. It was also revealed that a unit increase in LinkedIn usage at workplace would lead to an increase in employee productivity. This may be because of the fact that the platform is for mainly professionals from different disciplines sharing information and knowledge. Through LinkedIn, employees have the opportunity to build relationships with mutual connections and colleagues in the same field. These findings concur with Tarafdar et al. (2015) who noted that the usage of LinkedIn has been credited with helping employees to be $9 \%$ more productive in the workplace. In addition, the findings from the study agree with Maier et al. (2015) who opine that LinkedIn usage by employees can be strengthened for organisations when used to expand networks and increase access.

\section{Practical implications}

The findings from the study have several practical and theoretical implications. Basically, it was indicated from the study that engaging in the use of social networking sites such as WhatsApp, Twitter, Skype and Facebook in the workplace shares a negative relationship with employee productivity. From a practical point of view, the study conveyed a number of implications to government departments and human resource departments, in particular. It can be reasonably concluded that professionals in charge of human resource departments in both private and public sectors would benefit from understanding the nature of relationships between time spent on social media platforms and employee productivity elicited by the study.

Understanding relationships between the social media usage and employee productivity can help reveal the underlying rationale for organisations to either permit or disallow the use of social media in the workplace. As suggested by the findings, the social interaction of employees with friends, colleagues and family members through social networking sites during working hours does not enhance their productivity. At the same time, it was revealed that LinkedIn can help employees to be more productive. This suggests that organisations should help their employees to interact with co-workers and colleagues whilst in the workplace in order to obtain better workrelated outcomes. This is consistent with the work of Tajvidi and Karami (2017) who found that social and cognitive use of social media can have positive impact on employees' routine and innovative performance at work.

\section{Limitations and recommendations}

It should be noted that the growth of social media will continue and human resource practitioners in the government departments need to accept the reality. Thus, use of social media at workplace cannot be stopped in the present day but can only be managed to yield positive employee productivity. Based on the findings, there is the need for the government to put in regulations to ensure that time spent on social media during working hours is beneficial. In particular, the government departments can encourage employees to use social media to increase involvement, promote free flow of ideas, aid creativity and innovation. Given that social media will continue to remain popular, it is of profound importance to design and support interventions that would meet employee expectations to help them give off their best. As social media cannot be completely eradicated during working hours, the human resources departments should monitor deadlines and job deliverables with the need to ensure that jobs are performed efficiently. The human resources departments should focus on employee's behaviour towards using social media. In particular, it is important to design training programmes that will help employees to adjust habits of using social media at work.

The study on the effect of social media usage at workplace on employee productivity in the public sector was based on selected government departments in Harare. As such, the findings do not necessarily reflect the outlook of all government departments in the country. Since that restricted generalizability of the results, future work should explore more government departments and cover each of the provinces of the country. Future researches should also look at the impact of other social media network sites on employee productivity which were not discussed in the study. 


\section{Conclusion}

Findings from the study validated the view that use of social media by employees during working hours can be counterproductive. The study concluded that time spent and frequency of visit to social media during working hours can have negative effect on employee productivity. The study also concluded that social media resulted in significant drop in employees' productivity at workplace because of time spent online keeping in touch with friends, sharing pictures and communicating with colleagues. Specifically, it was concluded that using Facebook, Twitter, WhatsApp and Skype during working hours can have a negative influence on employee productivity. However, only LinkedIn showed a significant positive relationship with employee productivity. These findings indicate that if not well managed, social media participation may lead to a loss of productivity. The study concluded that employees can participate in social media in the workplace for various reasons including work-related and non-work-related reasons. Employee productivity can be enhanced if there are proper and effective ways of managing social media participation.

\section{Acknowledgements Competing interests}

The authors declare that they have no financial or personal relationships that may have inappropriately influenced them in writing this article.

\section{Authors' contributions}

The researchers worked hand in glove during the course of the study. To make the research more productive and efficient, J.S. formulated the research problem and synthesised relevant literature review. He was also involved in the distribution and collection of questionnaires from targeted respondents. T.W. provided the research methodology section as well as construction of research instrument. Both authors were involved in data collation, editing and analysis. The researchers also agreed on conclusions and recommendations. After completion of the research article, T.W. was involved in proofreading for grammar and logic.

\section{Funding information}

This research received no specific grant from any funding agency in the public, commercial or not-for-profit sectors.

\section{Data availability statement}

Data sharing is not applicable to this article as no new data were created or analysed in this study.

\section{Disclaimer}

The views and opinions expressed in this article are those of the authors and do not necessarily reflect the official policy or position of any affiliated agency of the authors.

\section{References}

Abdulahi, A., Samadi, B., \& Gharleghi, B. (2014). A study on the negative effects of social networking sites such as Facebook among Asia Pacific University scholars in Malaysia. International Journal of Business and Social Science, 5(10), 23-27.

Aguenza, B.B., Al-Kassem, A.H., \& Mat Som, A.P. (2012). Social media and productivity in the workplace: Challenge and constraints. Interdisciplinary Journal of Research in Business, 2(2), 22-26.

Aknin, L.B., Elizabeth, W.D., Ashley, V.W., Adam, M.G., \& Michael, I.N. (2013). Making a difference matter: Impacts unlocks the emotional benefits of pro-social spending. Journal of Economic Behaviour and Organization, 8(8), 90-95. https:// doi.org/10.1016/j.jebo.2013.01.008

Awolusi, M.F. (2012). The impacts of social networking sites on workplace productivity. The Journal of Technology, Management, and Applied Engineering, 28(1), 2-6.

Babbie, E., \& Mouton, J. (2012). The practice of social research. Oxford: Oxford University Press.

Bolton, R.N., Kabadayi, S., Gruber, T., Loureiro, Y.K., \& Solnet, D. (2013). Understanding generation $\mathrm{Y}$ and their use of social media: A review and research agenda. Journal of Service Management, 24(3), 245-267. https://doi.org/10.1108/0956423131 of Service

Bryman, A. \& Bell, E. (2015). Business research methods. Oxford: Oxford Publications.

Cai, Z., Huang, Q., \& Liu, H. (2018). Improving the agility of employees through enterprise social media: The mediating role of psychological conditions. International Journal of Information Management, 38(4), 52-63. https://doi.org/10.1016/j.ijinfomgt. 2017.09.001

Can, L., \& Kaya, N. (2016). Social networking sites addiction and the effect of attitude towards social network advertising. Procedia-Social and Behavioural Sciences, 235(6), 484-492. https://doi.org/10.1016/j.sbspro.2016.11.059

Cao, X., Vogel, D.R., Guo, X., Liu, H., \& Gu, J. (2012). Understanding the influence of social media in the workplace: An integration of media synchronicity and social capital theories. In 45th Hawaii International Conference on System Science (HICSS), 04-07 January 2012, Maui, HI, pp. 3938-3947.

Creswell, J.W. (2013). Qualitative inquiry \& research design choosing among five approaches (3rd edn.). London, Thousand Oaks.

De Wet, W., Koekemoer, E., \& Nel, J.A. (2016). Exploring the impact of information and communication technology on employees' work and personal lives. South African Journal of Industrial Psychology, 42(1), 1-11. https://doi.org/10.4102/sajip.v42i1.1330

Duff, B.R. L., \& Sar, S. (2015). Seeing the big picture: Multitasking and perceptual processing influences on ad recognition. Journal of Advertising, 44(3), 173-184. https://doi.org/10.1080/00913367.2014.967426

Easterby-Smith, M., Thorpe, R., \& Jackson, P. (2012). Management research (4th edn.). New Jersey: Prentice Hall.

Flynn, B.M. (2011). Do you Facebook? Networking with students online. College and Research Libraries News, 67(5), 306-307.

Gravili, G. (2010). Can cooperation in virtual social networks help organizations manage knowledge? In Proceedings of the European Conference on Information Management \& Evaluation, Cork, Ireland, 13-14 September 2012, pp. 109-117.

Hair, J.F. (2015). Essentials of business research methods. London: Pearson Education Limited.

Hair, J.F., Black, W.C., Babin, B.J., \& Anderson, R.E. (2010). Multivariate data analysis: A global perspective (7th edn.). London: Pearson.

Harandi, S.R., \& Abdolvand, N. (2018). Investigating the effect of online and offline workplace communication networks on employees' job performance: Considering the role of culture. Journal of Global Information Technology Management, 21(1), 26-44.

Holtzblatt, L., Drury, J.L., Weiss, D., Damianos, L.E., \& Cuomo, D. (2013). Evaluating the uses and benefits of an enterprise social media platform. Journal of Social Media for Organizations, 1(1), 1.

Hysa, B., Mularczyk, A., \& Zdonek, I. (2015). Social media: The challenges and the future direction of the recruitment process in HRM area. Studia Ekonomiczne, 2, 34, 54-69.

Jarrahi, M.H., \& Sawyer, S. (2012). Social technologies, informal knowledge practices, and the enterprise. Journal of Organizational Computing and Electronic Commerce, 23(1-2), 110-137. https://doi.org/10.1080/10919392.2013.748613

Kane, G.C. (2017). The evolutionary implications of social media for organizational knowledge management. Information and Organization, 27(1), 37-46.

Maier, C., Laumer, S., Weinert, C., \& Weitzel, T. (2015). The effects of techno stress and switching stress on discontinued use of social networking services: A study of Facebook use. Information Systems Journal, 25(3), 275-308.

Malhotra, N.K., (2010). Marketing research: An applied orientation (6th edn.). New Jersey: Prentice Hall.

Mhiripiri, N.A., \& Mutsvairo, B. (2013). Social media, new ICTs and the challenges facing the Zimbabwe Democratic process. Nairobi: IGI-Global Publications.

Mugenda, O., \& Mugenda, A.G. (2012). Research methods: Quantitative and qualitative approaches. Nairobi: ACTS.

Munar, A.M., Gyimóthy, S., \& Cai, L. (2013). Tourism social media: Transformations in identity, community and culture (p. 37). New York: Emerald Group Publishing.

Munene, Y.M. (2016). Effect of social media pertication in the workplace on employee productivity. International Journal of Advances in Management and Economics, 2(2), 141-150. 
Mushwana, G., \& Bezuidenhout, H. (2014). Social media policy in South Africa. Southern African Journal of Accountability and Auditing Research, 1(16), 63-74.

Naheed , T.J. (2014). Impact of social networking on employee performance. Business Management and Strategy, 5(2), 139-150. https://doi.org/10.5296/bms. v5i2.5978

Patel, N., \& Jasani, H. (2010). Social media security policies: Guidelines for organizations. Issues in Information Systems, XI(1), 628-634.

Razmerita, L., Philips-Wren, G., \& Jain, L.C. (2015). Innovations in knowledge management: The impact of social media, semantic web and cloud computing. Melbourne: Springer.

Ribière, V.M., Haddad, M., \& Philippe Vande, W. (2010). The impact of national culture traits on the usage of web 2.0 technologies, VINE, 4O(3/4), 334-361. https://doi. org/10.1108/03055721011071458

Richards, J. (2012). What has the internet ever done for employees? A review, map and research agenda. Emerald, 34(1), 22-43. https://doi.org/10.1108/014254512 11183246

Salanova, M., Llorens, S., \& Ventura, M. (2014). Technostress: The dark side of technologies. In C. Korunka \& P. Hoonakker (Eds.), The impact of ICT on quality of working life (pp. 87-103). Berlin: Springer.

Salkind, N.J. (2012). Exploring research (8th edn.). New York: Pearson.

Sanders, G.S., Baron, R.S., \& Moore, D.L. (1978). Distraction and social comparison as mediators of social facilitation effects. Journal of Experimental Social Psychology, 14(3), 291-303. https://doi.org/10.1016/0022-1031(78)90017-3

Scandura, T.A., \& Williams, E.A. (2013). Research methodology in management: Current practices, trends, and implications for future research. Academy of Management Journal, 43(6), 1248-1264. https://doi.org/10.2307/1556348

Sekaran, U., \& Bougie, R. (2013). Research methods for business: A skill building approach (6th edn.). New Delhi: Wiley.

Shami, N., Nichols, J., \& Chen, J. (2014). Social media participation and performance at work: A longitudinal study. In Proceedings of the CHI, 26 April-01 May 2014 (pp. 115-118). Toronto, Ontario, Canada. https://doi/org/10.1145/2556288 2557417

Shava, H., Chinyamurindi, W.T., \& Somdyala, A. (2016). An investigation into the usage of mobile phones among technical and vocational educational and training students in South Africa. South African Journal of Information Management 18(1), 1-8. https://doi.org/10.4102/sajim.v18i1.716
Speier, C., Valacich, J.S., \& Vessey, I. (1999). The influence of task interruption on individual decision making. Decision Sciences, 30(2), 33-36.

Sultana, N., Abdullah, A.M., \& Tabassum, A. (2013). Exploring the communication barriers in private commercial banks of Bangladesh. International Journal of Research Studies in Management, 2(1), 21-32. https://doi.org/10.5861/ijrsm. 2012.140

Tajvidi, R., \& Karami, A. (2017). The effect of social media on firm performance. Computers in Human Behaviour, 30, 1-10. https://doi.org/10.1016/j.chb.2017. 09.026

Tarafdar, M., Pullins, E. B. \& Ragu-Nathan, T.S. (2015). Technostress: Negative effect on performance and possible mitigations. Information Systems Journal, 25(2), 103132. https://doi.org/10.1111/isj.12042

Tilahun, M., \& Yeshambel, B. (2016). Impact of online social networking on employees productivity at work place in University of Gondar - A case study. International Journal of Computer Applications, 8(1), 18-24. https://doi.org/10.5120/ijca2016 907844

Twenge, J.M. (2010). A review of the empirical evidence on generational differences in work attitudes. Journal of Business and Psychology, 25(2), 201-210. https://doi. org/10.1007/s10869-010-9165-6

Von, V. (2015). Facebook status updates: Psychological correlates and consequences. Retrieved from http://www.diss.fuberlin.de/diss/servlets/MCRFileNodeServlet/ FUDISS_derivate_000000018587/Dissertation_grosse_Deters.pdf.

Wang, M.-H., Yang, T.-Y., \& Chen, Y.-S. (2016). How workers engage in social networking sites at work: A uses and gratification expectancy perspective. Internationa Journal of Organizational Innovation, 8(4), 161-176.

Wiid, J., \& Diggines, C. (2011). Marketing Research. Cape Town: Juta and Company Ltd.

Wilson, L. (2009). Facebook fixation harms student grades. The Australian. Retrieved from http://www.theaustralian.news.com.au/story/0,24897,25325762-12332,00. html.

Young, J.A. (2017). Facebook, Twitter, and Blogs: The adoption and utilization of socia media in non-profit human service organizations. Human Service Organizations: Management, Leadership \& Governance, 41(1), 44-57. https://doi.org/10.1080/2 3303131.2016.1192574

Zikmund, W.G., Babin, B.J., Carr, J.C., \& Griffin, M. (2013). Business research methods. New Jersey: Cengage Learning. 